\title{
Pengembangan E-modul Berbasis Penelitian Uji Antimikroba pada Matakuliah Mikrobiologi
}

\author{
Rochmatul Ummah ${ }^{1}$, Endang Suarsini ${ }^{1}$, Sri Rahayu Lestari ${ }^{1}$ \\ ${ }^{1}$ Pendidikan Biologi-Universitas Negeri Malang
}

\begin{tabular}{l}
\hline INFO ARTIKEL \\
\hline Riwayat Artikel: \\
Diterima: $27-04-2018$ \\
Disetujui: $11-05-2020$ \\
\hline
\end{tabular}

\section{Kata kunci:}

E-module;

antimicrobial test;

microbiology;

E-modul;

uji antimikroba;

mikrobiologi

\author{
Alamat Korespondensi: \\ Rochmatul Ummah \\ Pendidikan Biologi \\ Universitas Negeri Malang \\ Jalan Semarang 5 Malang \\ E-mail: rochmatulummah1993@gmail.com
}

\begin{abstract}
ABSTRAK
Abstract: This study aim was to develop an e-module based on antimicrobial test studies in microbiology courses. Type of research used is research and development with ADDIE model development. The study subject was student of State University of Malang who has taken the course of Microbiology. The instrument used is questionnaire validation of material and media experts and questionnaires for students. The percentage of results from material expert validation is $95 \%$, the media expert's validation is $98 \%$ and the readability test is $88 \%$. Based on the result, it can be concluded that e-module based on antimicrobial test research is valid and feasible to be used as teaching material in microbiology course.
\end{abstract}

\begin{abstract}
Abstrak: Tujuan penelitian ini untuk mengembangkan e-modul berbasis penelitian uji antimikroba pada matakuliah mikrobiologi. Jenis penelitian yang digunakan adalah penelitian dan pengembangan (Research and Development) dengan model pengembangan ADDIE. Subjek uji coba adalah mahasiswa S1 Universitas Negeri Malang yang telah menempuh matakuliah Mikrobiologi. Instrumen yang digunakan adalah angket validasi ahli materi dan media serta angket keterbacaan untuk mahasiswa. Persentase hasil dari validasi ahli materi adalah $95 \%$, validasi ahli media adalah $98 \%$ dan uji keterbacaan adalah $88 \%$. Berdasarkan hasil tersebut dapat disimpulkan bahwa e-modul berbasis penelitian uji antimikroba valid dan layak digunakan sebagai bahan ajar pada matakuliah mikrobiologi.
\end{abstract}

Mikrobiologi merupakan suatu cabang ilmu pengetahuan yang mempelajari tentang organisme berukuran mikro atau sangat kecil (Haagen \& Rintelen, 1941) dan untuk dapat melihatnya dibutuhkan sebuah alat bantu mikroskop dengan bahan kajian baik manfaat maupun kerugiannya (Hands-on, 2016). Mikrobiologi saat ini merupakan ilmu yang sedang berkembang dengan ilmuilmu yang lainnya seperti genetika mikroba, mikrobiologi air, tanaman, industri, makanan, mikrobiologi udara dan mikrobiologi lingkungan (Faridah \& Sari, 2019). Perkembangan mikrobiologi dalam pendidikan dianggap penting untuk diberikan bagi mahasiswa di perguruan tinggi (Hasmiati et al., 2016) salah satu perguruan tinggi yang memberikan tempat untuk belajar mikrobiologi adalah Universitas Negeri Malang. Mikrobiologi termasuk matakuliah Keilmuan dan Keterampilan (MKK) yang wajib ditempuh oleh seluruh mahasiswa Biologi pada semester empat atau semester genap (Universitas Negeri Malang, 2016). Pembelajaran mikrobiologi di UM dapat dilihat dari hasil observasi, angket, dan wawancara kepada dosen pengampu matakuliah dan mahasiswa yang telah menempuh mikrobiologi.

Hasil angket analisis kebutuhan yang diberikan kepada 46 mahasiswa yang telah menempuh matakuliah mikrobiologi di Universitas Negeri Malang sebagai berikut. Pertama, 86,96 \% mahasiswa merasa senang terhadap mikrobiologi. Kedua, $54,35 \%$ siswa menyatakan bahwa materi yang paling dirasa sulit adalah mikrobiologi kesehatan. Ketiga, 65,22\% mahasiswa menyatakan bahwa selama perkuliahan berlangsung mereka belum pernah melakukan eksperimen. Keempat, 77,91\% mahasiswa mampu mengakses e-learning dengan baik. Hasil analisis kebutuhan yang diberikan kepada salah satu Dosen matakuliah mikrobiologi dan 46 mahasiswa yang telah menempuh matakuliah mikrobiologi mendapatkan kesimpulan sebagai berikut: (1) metode yang sering dilakukan adalah diskusi dan presentasi; (2) belum terdapat bahan ajar utama yang dapat menunjang pembelajaran teori biologi, namun sudah terdapat buku petunjuk praktikum sebagai pegangan mahasiswa dalam praktikum; (3) praktikum dilakukan dengan bantuan asisten dengan peralatan dan bahan yang telah disiapkan sebelumnya; (4) $54,35 \%$ mahasiswa merasa kesulitan dengan teori tentang mikrobiologi kesehatan, dengan ketuntasan belajar sebanyak 60 $90 \%$. 
Kesimpulan yang didapatkan dari hasil analisis kebutuhan yang telah dilakukan didapatkan permasalahan dimana seharusnya terdapat bahan ajar yang menjadi patokan pasti dalam pembelajaran. Hal tersebut tentunya dapat mempersulit mahasiswa dalam belajar mikrobiologi, terutama pada materi mikrobiologi kesehatan yang merupakan materi dengan kesulitan tertinggi yang dirasakan oleh mahasiswa sehingga harus ada solusi mengenai bahan ajar yang sesuai untuk pembelajaran mikrobiologi di UM.

Materi tentang mikrobiologi kesehatan dirasa sulit oleh mahasiswa karena banyaknya metode uji antimikroba, namun kurang diimbangi dengan bahan ajar yang diberikan. Bahan ajar berupa petunjuk praktikum hanya ada penjelasan mengenai satu macam uji coba yang dapat digunakan dalam uji antimikroba sehingga pengalaman belajar mahasiswa terbatas hanya pada satu metode uji. Oleh karena itu, perlu dilakukan penelitian tentang uji antimikroba dengan metode uji yang lain sehingga dapat memberikan wawasan baru terhadap mahasiswa. Hasil dari uji antimikroba yang dilakukan akan digunakan sebagai salah satu penyusunan bahan ajar yang dikembangkan. Bahan ajar yang mampu memenuhi kebutuhan mahasiswa untuk bereksperimen secara mandiri adalah bahan belajar berupa modul.

Modul merupakan bahan belajar yang disusun secara lengkap dan sistematis, meliputi tujuan, materi, metode, dan evaluasi (Pantiwati, 2016) serta dirancang untuk pembelajaran mandiri sehingga dilengkapi dengan petunjuk penggunaan bagi peserta didik dan bagi pendidik (Setiyadi, 2017) untuk mempermudah tercapainya tujuan belajar yang telah ditentukan (Sungkono, 2009). Seiring dengan perkembangan zaman, pada saat ini dikenal dengan era abad 21 yang dicirikan oleh perkembangan teknologi informasi (Kusuma, 2011), maka modul yang dikembangkan sebaiknya berupa modul elektronik atau E-modul (Prawiradilaga et al., 2018).

Kelebihan dari penggunaan e-modul dalam pembelajaran, antara lain dapat membuat proses pembelajaran lebih menarik karena banyak desain yang disajikan dilengkapi dengan animasi (Arsal et al., 2019) pembelajaran lebih interaktif karena pebelajar dapat berinteraksi dengan e-modul yang digunakan (Abidin \& Walida, 2017) bahan ajar yang digunakan tidak hanya dapat digunakan sebagai ruang baca, namun juga dapat digunakan sebagai ruang instropeksi diri terhadap topik yang sedang dipelajarinya dari adanya evaluasi pembelajaran (Sirate \& Ramadhana, 2017) penggunaan e-modul juga dapat memudahkan pemahaman materi melalui gambar dan video (Hughes, 2002), serta dapat meningkatkatkan keterampilan abad 21 seperti keterampilan berpikir kritis (Suarsana \& Mahayukti, 2013) dan keterampilan proses sains (Peniati et al., 2013); (Rosa, 2015); (Susilawati et al., 2016); (Jumadi et al., 2018). Tujuan penelitian ini adalah untuk mengembangkan e-modul berbasis penelitian uji antimikroba pada matakuliah mikrobiologi untuk mahasiswa S1 Universitas Negeri Malang.

\section{METODE}

Jenis penelitian ini termasuk penelitian dan pengembangan (research and development) dengan menggunakan model pengembangan ADDIE yang terdiri dari lima tahapan, yaitu Analysis (Analisis), Design (Desain), Deevelopment (Pengembangan), Implemetation (Implementasi), dan Evaluation (Evaluasi). Instrumen yang digunakan berupa lembar validasi untuk ahli materi dan media serta angket keterbacaan dengan mahasiswa angkatan 2015 S1 Pendidikan Biologi Universitas Negeri Malang. Data dianalisis menggunakan analisis deskriptif kualitatif dari komentar dan saran para validator dan subjek uji coba, serta analisis deskriptif kuantitatif dari nilai hasil validasi yang telah dipersentasekan. Hasil analisis data kemudian disimpulkan berdasarkan kriteria kualifikasi penilaian yang diadaptasi dari Arikunto (2013) dimana terdapat lima keputusan uji, yaitu dapat digunakan tanpa revisi untuk hasil pencapaian 100\%; dapat dignakan namun perlu revisi kecil untuk hasil pencapaian 85,94-99,99\%; dapat digunakan namun perlu direvisi untuk hasil pencapaian 67,18-85,93\%; disarankan tidak digunakan karena banyak revisi untuk hasil pencapaian 48,55-67,17\%; tidak boleh digunakan untuk hasil pencapaian 25,00 $48,43 \%$.

\section{HASIL}

Penelitian dan pengembangan ini mengacu pada model pengembangan ADDIE yang terdiri atas lima tahapan, yaitu Analysis (Analisis), Design (Desain), Deevelopment (Pengembangan), Implemetation (Implementasi), dan Evaluation (Evaluasi). Hasil dari masing-masing tahapan adalah sebagai berikut.

\section{Analysis (Analisis)}

Pertama, Hasil dari analisis RPS yang telah dilakukan diketahui bahwa capaian pembelajaran yang diterapkan pada matakuliah mikrobiologi tersebut masih belum sepenuhnya mengaplikasikan kualifikasi dalam KKNI berdasarkan jenjang S1 yang terkait karena didalamnya hanya memuat pengaplikasian bidang keahlian sesuai IPTEK sesuai bidangnya dan penguasaan konsep teoritis bidang pengetahuan secara umum dan konsep teoritis bagian khusus dalam bidang pengetahuan serta mampu menyelesaikan masalah prosedural, namun tidak memuat kompetensi dalam hal mengambil keputusan yang tepat sesuai dengan permasalahan yang ditemukan, menganalisis informasi, dan data secara mandiri. 
Kedua, Hasil dari analisis kebutuhan mahasiswa diketahui bahwa terdapat permasalahan dalam pembelajaran mikrobiologi yakni terkait dengan bahan ajar karena belum ada bahan ajar khusus yang menjadi pedoman mahasiswa untuk belajar serta belum diberikan adanya kebebasan bereksperimen untuk mengasah keterampilan mahasiswa karena mahasiswa selalu melakukan eksperimen seperti apa yang ada di buku petunjuk praktikum. Hasil analisis kebutuhan juga diketahui bahwa materi yang dirasa sulit oleh mahasiswa adalah mikrobiologi kesehatan.

Hasil analisis yang telah dilakukan melatarbelakangi peneliti untuk mengembangkan sebuah e-modul mikrobiologi dengan materi mikrobiologi kesehatan yang dilengkapi dengan hasil penelitian uji antimikroba untuk membantu mahasiswa untuk bereksperimen secara bebas dan untuk melatih kompetensi dalam hal mengambil keputusan sesuai dengan permasalahan yang ditemukan.

\section{Design (Desain)}

Desain awal e-modul yang akan dikembangkan adalah terdiri dari enam menu utama yang tersaji pada tabel 1.

Tabel 1. Desain Awal E-modul

\begin{tabular}{cll}
\hline No. & \multicolumn{1}{c}{ Menu } & Isi Menu \\
\hline 1 & Petunjuk penggunaan & Berisi petunjuk penggunaan e-modul yang dapat mempermudah mahasiswa belajar dengan e-modul \\
\hline 2 & $\begin{array}{l}\text { Pengenaan mikrobiologi } \\
\text { kesehatan }\end{array}$ & $\begin{array}{l}\text { Berisi penjelasan singkat mengenai awal mula adanya mikrobiologi kesehatan serta perkembangannya dari } \\
\text { waktu ke waktu }\end{array}$ \\
\hline 3 & Kegiatan belajar I & $\begin{array}{l}\text { Berisi materi pembelajaran mengenai peranan menguntungkan dan merugikan mikroba, tujuan } \\
\text { pembelajaran yang harus dicapai oleh mahasiswa, lembar kegiatan mahasiswa yang dibuat dengan } \\
\text { mengacu pada tahapan inkuiri serta evaluasi belajar. }\end{array}$ \\
\hline 4 & Kegiatan belajar II & $\begin{array}{l}\text { Berisi materi pembelajaran mengenai uji antimikroba dengan menggunakan metode dilusi, tujuan } \\
\text { pembelajaran yang harus dicapai oleh mahasiswa, lembar kegiatan mahasiswa yang dibuat dengan } \\
\text { mengacu pada tahapan inkuiri serta evaluasi belajar. }\end{array}$ \\
\hline 5 & Pengayaan & $\begin{array}{l}\text { Berisi rangkaian percobaan yang dilakukan oleh penelitian serta hasil dan pembahasan mengenai penelitian } \\
\text { uji antimikroba dengan metode dilusi yang dilakukan oleh peneliti }\end{array}$ \\
\hline 6 & Penutup & Berisi daftar rujukan dan glosarium \\
\hline
\end{tabular}

\section{Development (Pengembangan)}

Pada tahap ini peneliti mengembangkan produk berupa e-modul seperti rancangan awal yang kemudian divalidasi oleh ahli media dan materi untuk mengetahui kevalidan dari e-modul yang dikembangkan serta di uji keterbacaan oleh mahasiswa $\mathrm{S} 1$ Pendidikan Biologi angkatan 2015 Universitas Negeri Malang yang terdiri atas uji perorangan, uji kelompok kecil, dan uji kelompok besar. Hasil validasi dan uji keterbacaan adalah sebagai berikut.

\section{Hasil validasi oleh ahli materi}

E-modul yang dikembangkan divalidasi oleh ahli materi yang mempunyai keahlian dalam bidang mikrobiologi kesehatan. Hasil validasi oleh ahli materi mendapat rata-rata dari semua aspek sebesar $96 \%$ yang dapat disimpulkan bahwa emodul yang dikembangkan layak dengan sedikit revisi. Jumlah persentase dari setiap aspek dapat dilihat pada gambar 1.

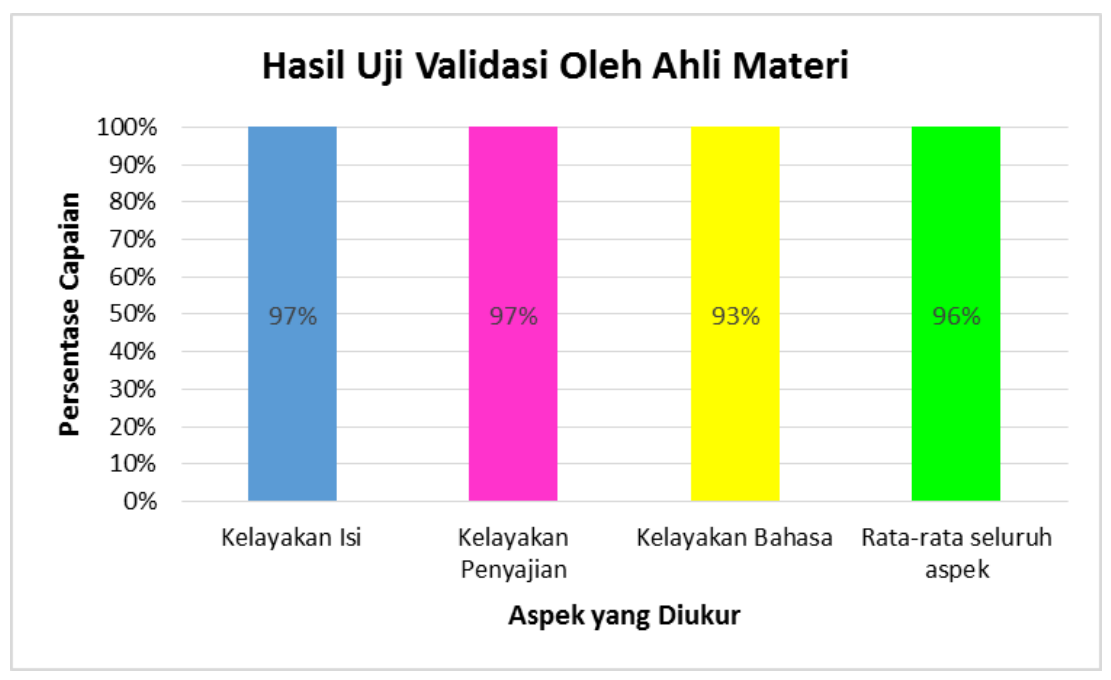

Gambar 1. Diagram Hasil Uji Validasi Ahli Materi 
Tabel 2

Adapun saran dan komentar dari validator ahli materi serta perbaikan yang dilakukan oleh peneliti dapat dilihat pada

Tabel 2. Saran dan Komentar dari Validator Ahli Materi serta Perbaikan dari Peneliti

\begin{tabular}{cll}
\hline No. & \multicolumn{1}{c}{ Saran dan Komentar dari Validator Ahli Materi } & \multicolumn{1}{c}{ Perbaikan dari Peneliti } \\
\hline 1 & $\begin{array}{l}\text { Pada materi pengenalan mikrobiologi kesehatan perlu dituliskan juga } \\
\text { tahun penelitian atau tahun teori mikrobiologi kesehatan ditemukan }\end{array}$ & $\begin{array}{l}\text { Menambahkan tahun penelitian yang dilakukan oleh } \\
\text { setiap ahli mikrobiologi dan perkembangan selanjutnya }\end{array}$ \\
\hline 2 & $\begin{array}{l}\text { Perlu ditambahkan juga gambar mengenai penyakit pertama kali yang } \\
\text { menyerang hewan, tidak hanya penyakit yang menyerang tumbuhan }\end{array}$ & $\begin{array}{l}\text { Menambahkan gambar penyakit pertama kali yang } \\
\text { menyerang hewan, yaitu penyakit pabrine pada ulat sutra }\end{array}$ \\
\hline 3 & $\begin{array}{l}\text { Baik dalam materi atau evaluasi pembelajaran tidak boleh menyinggung } \\
\text { kata yang mengandung SARA (Suku, Agama, Ras, dan Antar golongan) }\end{array}$ & $\begin{array}{l}\text { Mengganti pilihan jawaban pada evaluasi yang } \\
\text { menyinggung kata yang mengandung SARA }\end{array}$ \\
\hline
\end{tabular}

\section{Hasil validasi dari Ahli Media}

E-modul divalidasi juga oleh ahli media yang mempunyai keahlian dalam bidang media pembelajaran dan ilmu komunikasi. Hasil validasi oleh ahli media memperoleh rata-rata seluruh aspek sebesar 99\% yang artinya e-modul yang dikembangkan layak digunakan. Hasil peresentase dari setiap aspek yang divalidasi dapat dilihat pada gambar 2 .

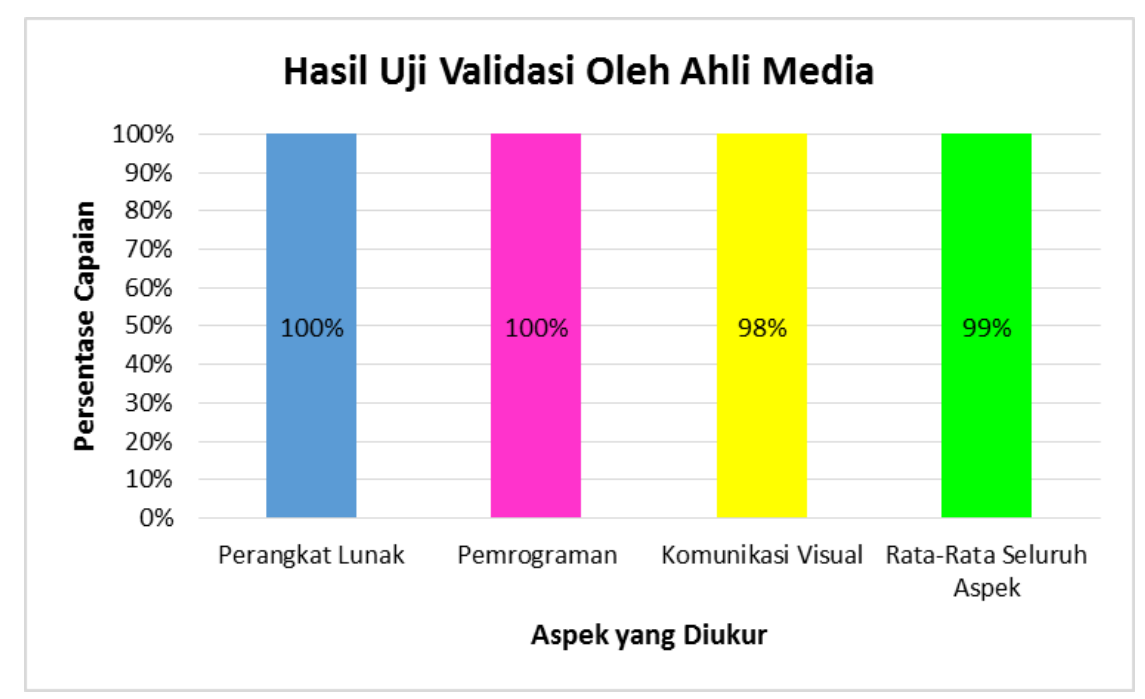

Gambar 2. Diagram Hasil Uji Validasi Ahli Media

Saran dari validator ahli media adalah domain yang digunakan dimasukkan ke ac/sch/org, bukan com karena domain com biasanya tidak dipercaya sebagai domain asli. Namun, saran dari beliau belum bisa dijalankan sebab peneliti masih belum mendapatkan izin untuk masuk ke domain yang disarankan.

\section{Hasil Uji Keterbacaan}

Uji keterbacaan dilakukan oleh mahasiswa S1 Pendidikan Biologi Fakultas Matematika dan Ilmu Pengetahuan Alam angakatan 2015, Universitas Negeri Malang yang telah menempuh matakuliah mikrobiologi. Uji keterbacaan dibagi menjadi tiga kelompok, antara lain uji perorangan dengan menggunakan dua sampel, uji kelompok kecil dengan menggunakan 10 sampel dan uji kelompok besar dengan menggunakan 20 sampel. Hasil dari setiap kelompok uji adalah sebagai berikut.

\section{Hasil Uji Perorangan}

Uji perorangan dilakukan dengan menggunakan dua sampel. Hasil persentase dari angket keterbacaan adalah sebesar 90\% sehingga dapat dikatakan bahwa e-modul yang dikembangkan layak untuk dijadikan sumber belajar mikrobiologi. Adapaun saran dan komentar dari uji perorangan berhubungan dengan jenis dan ukuran font yang digunakan dalam e-modul. Dengan demikian, peneliti melakukan perbaikan dengan mengganti font dan ukuran sehingga lebih mudah untuk dibaca. 


\section{Hasil Uji Kelompok Kecil}

Uji kelompok kecil dilakukan dengan menggunakan 10 sampel. Hasil yang didapatkan dari uji kelompok kecil adalah sebesar 90\% sehingga dapat dikatakan bahwa e-modul yang dikembangkan layak dengan sedikit revisi. Saran dan komentar dari uji kelompok kecil adalah masih ada beberapa kata yang salah ketik dan background e-modul sebaiknya yang berhubungan dengan mikrobiologi, bukan tumbuhan agar sesuai dengan materi yang ada dalam e-modul. Peneliti kemudian melakukan perbaikan dengan mengganti penulisan yang salah ketik dan mengganti tiga background dari menu yang ada di e-modul yang sebelumnya bergambar tumbuhan mengganti dengan gambar mikroba.

\section{Hasil Uji Kelompok Besar}

Uji kelompok besar dilakukan dengan menggunakan 20 sampel. Hasil yang didapatkan dari uji kelompok besar adalah sebesar $88 \%$ sehingga dapat dikatakan bahwa e-modul yang dikembangkan layak digunakan sebagai bahan ajar mikrobiologi. Saran yang didapatkan dari uji kelompok besar adalah mengenai penambahan musik yang dapat diputar sewaktu-waktu oleh pembaca.

\section{PEMBAHASAN}

Mikrobiologi merupakan matakuliah yang bersifat abstrak karena objek yang dipelajari berupa mikroorganisme yang hanya dapat dilihat dengan alat bantu mikroskop. Oleh karena itu, diperlukan kegiatan praktikum untuk membuat materi dalam mikrobiologi bersifat konkret (Prayitno et al., 2017). Observasi yang dilakukan menunjukkan bahwa dalam matakuliah mikrobiologi sudah dilaksanakan kegiatan praktikum setiap minggunya, namun kegiatan yang dilakukan masih terbatas pada petunjuk praktikum yang didapat dari pembina matakuliah. Hal tersebut membuat kompetensi mahasiswa kurang terasah dalam hal kepekaan terhadap masalah yang berhubungan dengan materi ajarnya, kemampuan memecahkan masalah, mengambil keputusan yang tepat sesuai dengan permasalahan yang ditemukan, dan menganalisis informasi data secara mandiri sesuai dengan kompetensi yang dituntut oleh Kerangka Kualifikasi Nasional Indonesia (KKNI).

Permasalahan yang ditemukan dapat diatasi dengan mengembangkan bahan ajar yang berisi materi beserta kegiatan belajar yang harus dilakukan oleh mahasiswa untuk mendapatkan informasi dalam kehidupan sehari-hari terkait dengan materi yang dipelajari. Salah satu bahan ajar yang dapat dikembangkan adalah modul yang merupakan bahan ajar yang disusun secara lengkap dan sistematis meliputi tujuan, materi, metode, dan evaluasi (Sungkono, 2009) serta dirancang untuk pembelajaran mandiri (S.Sirate \& Ramadhana, 2017). Seiring dengan perkembangan era abad 21 yang banyak dicirikan oleh perkembangan teknologi informasi, maka modul yang dikembangkan sebaiknya berupa modul elektronik atau yang biasa disebut dengan emodul (Ummah et al., 2017).

E-modul yang dikembangkan berjudul "Emikes" yang merupakan singkatan dari E-modul Mikrobiologi Kesehatan. Emodul yang dikembangkan terdiri atas enam menu utama, yakni (1) petunjuk penggunaan yang berisi petunjuk umum dan khusus dalam untuk mahasiswa dalam mempelajari e-modul (Winkel, 2009). Petunjuk penggunaan ini bermanfaat untuk mahasiswa dalam belajar secara mandiri (Amri \& Ahmadi, 2010); (2) pengenalan mikrobiologi kesehatan yang berisi asal mula dipeloporinya mikrobiologi kesehatan dan bagaimana perkembangannya dari waktu ke waktu; (3) kegiatan Belajar I yang berisi tujuan pembelajaran, ringkasan materi, lembar kegiatan mahasiswa dan evaluasi pembelajaran. Kegiatan belajar I ini memuat materi tentang peranan menguntungkan dan merugikan mikroba dalam bidang kesehatan; (4) kegiatan belajar II berisi konten yang sama dengan kegiatan belajar I, namun dalam kegiatan belajar II materi yang dibahas adalah mengenai uji antimikroba untuk mengetahui keefektifan antimikroba terhadap mikroba uji; (5) pengayaan yang berisi penelitian uji antimikroba yang telah dilakukan sebelumnya oleh peneliti. Hasil penelitian uji antimikroba dapat menjadi salah satu contoh konkret dari materi yang dipelajari dengan informasi yang terbaru karena baru dilakukan penelitian; (6) penutup yang berisi daftar pustaka dan glosarium. E-modul yang dikembangkan kemudian divalidasi oleh validator ahli materi dan media.

E-modul yang sudah dikembangkan divalidasi oleh ahli materi dan ahli media. Hasil validasi oleh ahli media mendapatkan rata-rata seluruh aspek sebesar 96\% dengan rincian aspek kelayakan isi 97\%, aspek kelayakan penyajian 97\%, dan kelayakan bahasa 93\%. Berdasarkan kriteria kualifikasi penilaian oleh Arikunto (2013) hasil yang didapatkan dari validator ahli materi termasuk pada kategori valid karena hasil pencapaiannya antara 85,99—99,99\% dengan keputusan uji dapat digunakan sebagai bahan ajar, namun perlu revisi kecil. Revisi yang dilakukan oleh peneliti menurut komentar dan saran dari validator ahli materi, antara lain (1) menambahkan tahun penelitian atau tahun ditemukannya teori-teori tentang mikrobiologi kesehatan (dapat dilihat pada Gambar 3); (2) menambahkan gambar yang mewakili penyakit pertama pada hewan (dapat dilihat pada Gambar 4); (3) mengganti pilihan jawaban yang mengandung makna SARA (dapat dilihat pada Gambar 5). 


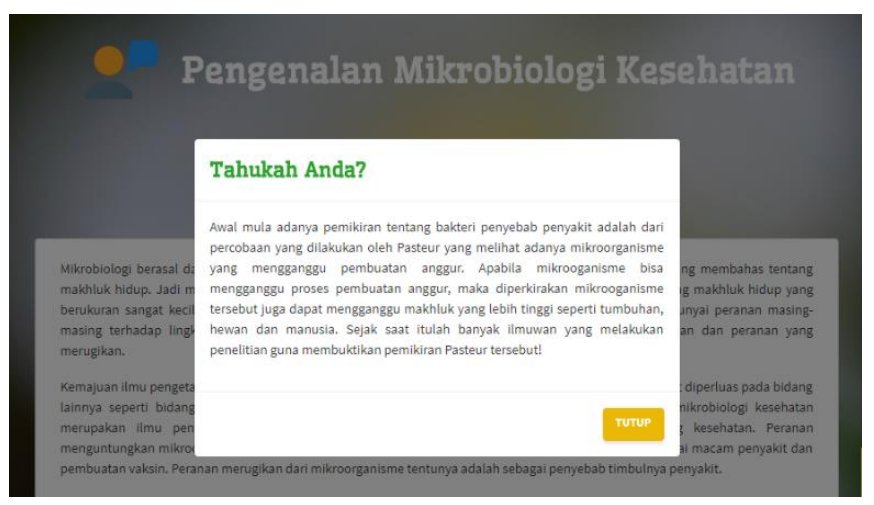

A. Sebelum Revisi

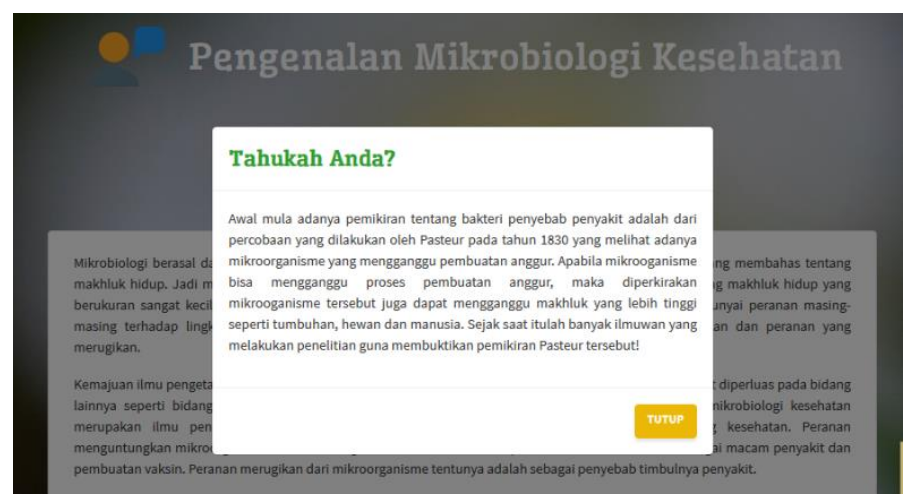

B. Sesudah Revisi

Gambar 3. Penambahan tahun saat Pasteur melakukan percobaan membuat anggur dan menemukan adanya mikroorganisme yang mengganggu
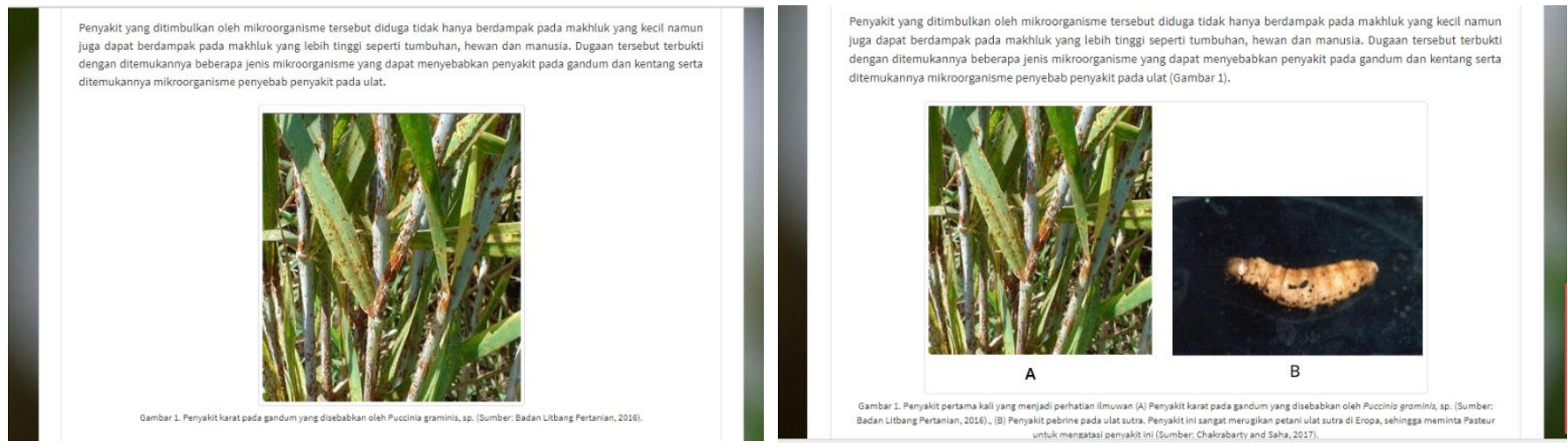

A. Sebelum Revisi

B. Sesudah revisi

Gambar 4. Penambahan gambar contoh penyakit pertama pada hewan, yaitu penyakit pabrine pada ulat sutra

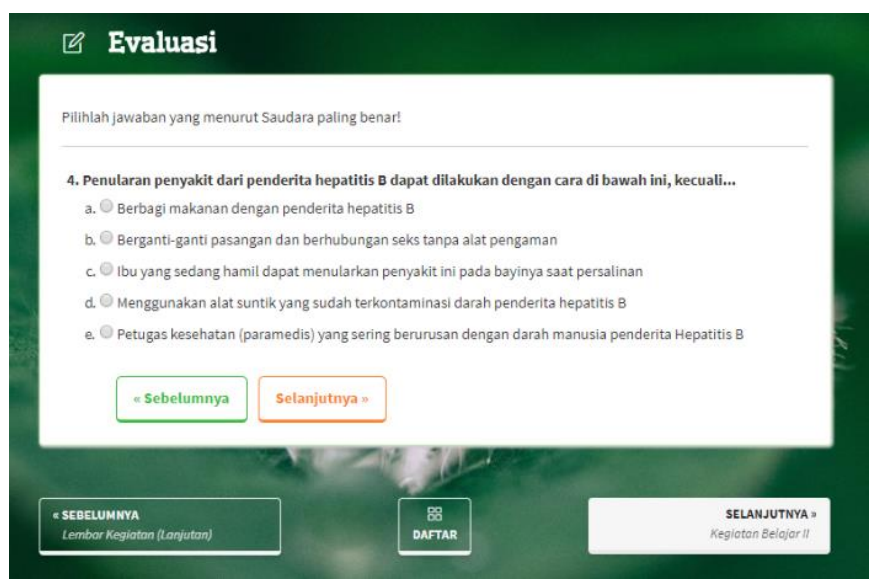

A. Sebelum Revisi

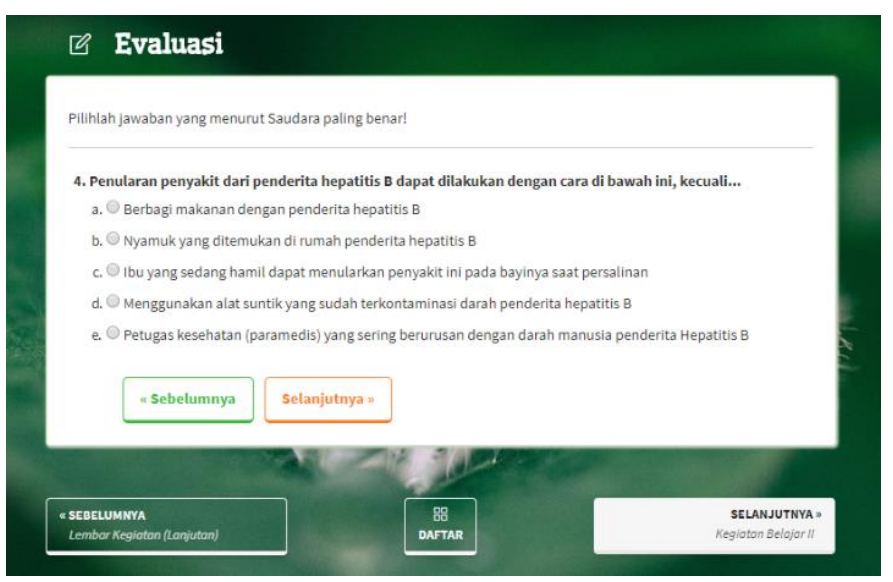

B. Sesudah revisi

Gambar 5. Penggantian pilihan jawaban b. yang dianggap mengandung makna SARA

E-modul yang dikembangkan juga divalidasi oleh ahli media. Hasil validasi oleh ahli media mendapatkan rata-rata seluruh aspek sebesar 99\% dengan rincian aspek perangkat lunak 100\%, aspek pemrograman 100\% dan kelayakan komunikasi visual 98\%. Berdasarkan kriteria kualifikasi penilaian oleh Arikunto (2013), hasil yang didapatkan dari validator ahli media termasuk pada kategori valid karena hasil pencapaiannya antara 85,94—99,99\% dengan keputusan uji dapat digunakan sebagai 
bahan ajar, namun perlu revisi kecil. Saran dari validator ahli media adalah mengganti domain web dari .com menjadi domain .ac/sch/org. Namun saran beliau belum bias dilakukan karena belum ada izin dari pengelola domain-domain tersebut. Emodul setelah dilakukan revisi atas saran dan komentar dari validator, kemudian diuji keterbacaannya oleh mahasiswa.

Ada tiga macam uji yang dilakukan oleh peneliti, yaitu uji perorangan, uji kelompok kecil, dan uji kelompok besar. Uji perorangan yang menggunakan dua sampel mahasiswa, satu berjenis kelamin laki-laki dan satu berjenis kelamin perempuan. Hal ini bertujuan untuk mengetahui bagaimana pendapat mahasiswa terkait perbedaan jenis kelamin (Sari, et al. 2006) mengenai e-modul yang dikembangkan. Hasil rata-rata seluruh aspek yang diuji dari uji perorangan adalah $90 \%$, dengan rincian setiap aspek (1) aspek rekayasa perangkat lunak 100\%; (2) aspek pemrograman 90\%; (3) aspek bahasa 88\%; (4) aspek keterbacaan 91\%; (5) aspek pengaruh e-modul terhadap mahasiswa 85\%; (6) aspek kemungkinan 84\%; dan (7) aspek kebermanfaatan 94\%. Berdasarkan kriteria kualifikasi penilaian, hasil yang didapatkan dari uji perorangan termasuk pada kategori valid dengan keputusan uji layak digunakan, namun perlu revisi kecil. Revisi yang dilakukan oleh peneliti berdasarkan saran subjek uji perorangan adalah mengganti jenis dan ukuran font pada materi agar lebih mudah untuk dibaca.

Uji kelompok kecil dilakukan dengan 10 mahasiswa yang telah menempuh matakuliah mikrobiologi. Hasil rata-rata seluruh aspek yang diuji sebesar 90\% dengan rincian setiap aspek, antara lain (1) aspek rekayasa perangkat lunak 92\%; (2) aspek pemrograman $89 \%$; (3) aspek bahasa 88\%; (4) aspek keterbacaan 87\%; (5) aspek pengaruh e-modul terhadap mahasiswa 90\%; (6) aspek kemungkinan 85\%; (7) aspek kebermanfaatan 97\%. Interpretasi hasil yang didapat dari uji kelompok kecil termasuk kedala kategori layak untuk digunakan sebagai bahan ajar dengan revisi kecil atas saran dan komentar yang diberikan. Saran dan komentar yang dilakukan revisi adalah mengganti background yang tidak berhubungan dengan mikroba menjadi gambar yang berhubungan dengan mikroba. Hal tersebut agar antara isi dan tampilan e-modul lebih serasi.

Uji kelompok besar dilakukan dengan 20 mahasiswa. Hasil rata-rata seluruh aspek yang diuji sebesar $88 \%$ dengan rincian setiap aspek adalah sebagai berikut: (1) aspek rekayasa perangkat lunak 91,5\%; (2) aspek pemrograman 87,75\%; (3) aspek bahasa $86 \%$; (4) aspek keterbacaan 87\%; (5) aspek pengaruh e-modul terhadap mahasiswa 89\%; (6) aspek kemungkinan $86 \%$; dan (7) aspek kebermanfaatan 90\%. Hasil rata-rata seluruh aspek dari uji kelompok besar dikatakan bahwa e-modul yang dikembangkan layak digunakan sebagai bahan ajar mikrobiologi kesehatan dengan revisi kecil. Komentar dari uji kelompok besar adalah didapatkan permasalahan gangguan pada web, seperti peringatan situs penipuan atau situs eror. Hal tersebut karena domain web yang free sehingga memungkinkan akses ke dalam web akan melambat apabila banyak yang menggunakan pada saat yang bersamaan. Keterbatasan peneliti menjadikan peneliti tidak dapat memperbaiki hal tersebut.

Apabila dilihat dari aspek yang diuji maka terdapat peningkatan atas aspek kebermanfaatan antara hasil dari uji perorangan dan uji kelompok kecil. Hal tersebut didukung oleh pernyataan salah satu mahasiswa bahwa "baru pertama kali menemukan modul yang berbentuk elektronik, dan e-modul ini mempermudah dalam proses belajar dan membantu mahasiswa untuk lebih memahami materi karena adanya gambar yang menarik dan video dalam materi". Pernyataan tersebut sesuai dengan hasil penelitian yang dilakukan oleh (Hartanto, 2016) dan (Wibowo, 2018) bahwa e-modul akan membuat proses pembelajaran lebih menarik karena adanya konten yang berwarna sehingga membuat pengguna tidak jenuh. Konten yang dimaksud adalah konten berupa gambar dan video yang tersaji dalam e-modul seperti pendapat dari (Hughes, 2002). Hal tersebut menjadikan materi lebih mudah diterima oleh pengguna (Nurchaili, 2010).

\section{SIMPULAN}

Penelitian dan pengembangan yang telah dilakukan menghasilkan bahan ajar berbentu e-modul dengan materi mikrobiologi kesehatan untuk matakuliah mikrobiologi dengan kriteria valid dan layak digunakan sebagai bahan ajar namun perlu sedikit revisi berdasarkan validasi ahli materi, media, dan uji keterbacaan.

\section{DAFTAR RUJUKAN}

Abidin, Z., \& Walida, S. El. (2017). Pengembangan E-Modul Interaktif Berbasis Case (Creative, Active, Systematic, Effective) Sebagai Alternatif Media Pembelajaran Geometri Transformasi untuk Mendukung Kemandirian Belajar dan Kompetensi Mahasiswa. Seminar Nasional Matematika dan Aplikasinya, 197-202.

Amri, S., \& Ahmadi, L. K. (2010). Konstruksi Pengembangan Pembelajaran: Pengaruhnya terhadap Mekanisme dan Praktik Kurikulum. Jakarta: Prestasi Pustakarya.

Arikunto, S. (2013). Prosedur Penelitian: Suatu Pendekatan Praktik. Jakarta: Rineka Cipta.

Arsal, M., Danial, M., \& Hala, Y. (2019). Pengembangan Media Pembelajaran E-Modul Materi Sistem Peredaran Darah pada Kelas XI MIPA SMAN 6 Barru. Prosiding Seminar Nasional Biologi VI, 434-442.

Faridah, H. D., \& Sari, S. K. (2019). Utilization of Microorganism on the Development of Halal Food Based on Biotechnology. Journal of Halal Product and Research, 2(1), 33. https://doi.org/10.20473/jhpr.vol.2-issue.1.33-43

Haagen, \& Rintelen, K. (1941). Mikrobiologie. Zeitschrift Für Krebsforschung, 52(2 Supplement), 90-91. https://doi.org/10.1007/BF01620495

Hands-on, K. T. (2016). Potensi Kitchen Microbiology untuk Meningkatkan Keterampilan Teknik Hands-on Dalam Pembelajaran Mikrobiologi. USEJ - Unnes Science Education Journal, 5(2), 1210-1216. https://doi.org/10.15294/usej.v5i2.12591

Hartanto, W. (2016). Penggunaan E-Learning sebagai Media Pembelajaran. Jurnal Pendidikan Ekonomi, 10(1), 1-18. 
Hasmiati., Syamsudduha, S., \& Jamilah. (2016). Hubungan Antara Pengetahuan Mikrobiologi dengan Sikap Higienis Mahasiswa Pendidikan Biologi Angkatan 2013 Fakultas Tarbiyah dan Keguruan UIN Alauddin Makassar. Jurnal Biotek, 4(2), 231-243.

Jumadi, J., Sunarno, W., \& Aminah, N. S. (2018). Pengembangan Modul IPA Berbasis Keterampilan Proses Sains untuk Meningkatkan Kemampuan Berpikir Kritis Peserta Didik Kelas VII SMP pada Materi Kalor. INKUIRI: Jurnal Pendidikan IPA, 7(2), 262. https://doi.org/10.20961/inkuiri.v7i2.22986

Nurchaili. (2010). Pengaruh Media Pembelajaran Berbasis Teknologi Informasi Dalam Proses Pembelajaran Kimia terhadap Peningkatan Hasil Belajar Siswa. Jurnal Pendidikan dan Kebudayaan, 16(6), 648. https://doi.org/10.24832/jpnk.v16i6.493

Pantiwati, Y. (2016). Pengembangan Modul Evaluasi Pembelajaran dengan Model Pembelajaran 7E Berbasis Kreativitas. Proceeding Biology Education Conference, 13(1), 13 (1), 461-467.

Peniati, E., Ipa, P. P., Matematika, F., \& Alam, P. (2013). Pengembangan Modul Pembelajaran IPA Terpadu Berpendekatan Keterampilan Proses pada Tema Dampak Limbah Rumah Tangga terhadap Lingkungan Untuk SMP Kelas VIII. USEJ Unnes Science Education Journal, 2(2). https://doi.org/10.15294/usej.v2i2.2043

Prawiradilaga, D. S., Widyaningrum, R., \& Ariani, D. (2018). Prinsip-Prinsip Dasar Pengembangan Modul Berpendekatan Hypercontent. Indonesian Journal of Curriculum and Educational Technology Studies, 5(2), 57-65. https://doi.org/10.15294/ijcets.v5i2.17098

Prayitno, T. A., Hidayati, N., Biologi, P., Pendidikan, F., Eksakta, I., Biologi, P. P., Pendidikan, F., \& Eksakta, I. (2017). Pengembangan Multimedia Interaktif Bermuatan Materi, 3(2), 86-93.

Rosa, F. O. (2015). Pengembangan Modul Pembelajaran IPA SMP pada Materi Tekanan Berbasis Keterampilan Proses Sains. Jurnal Pendidikan Fisika, 3(1). https://doi.org/10.24127/jpf.v3i1.21

S.Sirate, S. F., \& Ramadhana, R. (2017). Pengembangan Modul Pembelajaran Berbasis Keterampilan Literasi. Inspiratif Pendidikan, 6(2), 316. https://doi.org/10.24252/ip.v6i2.5763

Setiyadi, M. W. (2017). Pengembangan Modul Pembelajaran Biologi Berbasis Pendekatan Saintifik untuk Meningkatkan Hasil Belajar Siswa. Journal of Educational Science and Technology (EST), 3(2), 102. https://doi.org/10.26858/est.v3i2.3468

Suarsana, I. M., \& Mahayukti, G. A. (2013). Pengembangan E-Modul Berorientasi Pemecahan Masalah untuk Meningkatkan Keterampilan Berpikir Kritis Mahasiswa. Jurnal Nasional Pendidikan Teknik Informatika (JANAPATI), 2 (3), 193. https://doi.org/10.23887/janapati.v2i3.9800

Sungkono. (2009). Pengembangan dan Pemanfaatan Bahan Ajar Modul Dalam Proses Pembelajaran. Majalah Ilmiah Pembelajaran, 5(1).

Susilawati, Neneng, L., \& Miranda, Y. (2016). Pengembangan Modul Pembelajaran Biologi untuk Meningkatkan Keterampilan Proses Sains dan Hasil Belajar Siswa SMA Kelas X. Edu-Sains, 4(2), 104-114.

Ummah, R., Suarsini, E., \& Lestari, S. R. (2017). Analisis Kebutuhan Pengembangan E-Modul Berbasis Penelitian Uji Antimikroba pada Matakuliah Mikrobiologi. 2, 555-562.

Wibowo, E. (2018). Modul Elektronik Guna Mengembangkan Bahan Ajar. http://repository.radenintan.ac.id/3420/1/SKRIPSI FIX EDI.pdf

Winkel. (2009). Psikologi Pengajaran. Yogyakarta: Media Abadi. 